\title{
Dietary Supplementation of Lactobacillus Sporogenes on Performance and Serum Biochemico - Lipid Profile of Broiler Chickens
}

\author{
Arun K. Panda, Savaram V. Rama Rao, Mantena V.L.N. Raju and Sita R. Sharma \\ Project Directorate on Poultry, Rajendranagar Hyderabad 500 030, India
}

\begin{abstract}
An experiment was conducted to study the effect of dietary supplementation of probiotic Lactobacillus sporogenes (L. sporogenes) on performance and serum biochemico-lipid profile of broiler chickens. One hundred and twenty, day-old commercial broiler chicks were distributed equally into 3 groups of 40 chicks each, which was further replicated to 8 groups of 5 each. The chicks were placed on one of three dietary treatments : basal, basal with probiotic ( $6 \times 10^{8}$ spore of Lactobacillus sporogenes per g) at 100 or $200 \mathrm{mg}$ per $\mathrm{kg}$ feed. Body weight gain increased and feed conversion ratio improved significantly due to dietary supplementation of $100 \mathrm{mg}$ probiotic per kg diet. However, no further benefits on the above parameters could be observed by increasing the level of supplementation from 100 to $200 \mathrm{mg}$ per $\mathrm{kg}$. Leg abnormality score is not influenced by probiotic supplementation in the diet. However, the bone breaking strength and bone ash content increased significantly by probiotic supplementation at $100 \mathrm{mg}$ per $\mathrm{kg}$ diet. The concentration of protein and calcium increased significantly due to dietary supplementation of $L$. sporogenes. Neither concentration of inorganic phosphorus nor activities of enzymes such as serum glutamate-oxaloacetate transminae (SGOT), serum glutamate-pyruvate transaminase (SGPT) and alkaline phosphatase (ALP) in serum were influenced due to L. sporogenes supplementation. Serum total cholesterol, low-density lipoprotein (LDL) cholesterol, very low-density lipoprotein (VLDL) cholesterol and triglycerides were reduced significantly by dietary supplementation of $L$. sporogenes at $100 \mathrm{mg}$ per $\mathrm{kg}$ diet. However, high-density lipoprotein (HDL) cholesterol of birds was not influenced by $L$. sporogenes supplementation. It is concluded that dietary supplementation of Lactobacillus sporogenes $\left(6 \times 10^{8}\right.$ spore per $\left.\mathrm{g}\right)$ at $100 \mathrm{mg}$ per $\mathrm{kg}$ diet significantly enhanced body weight gain, improved feed conversion ratio, bone ash and bone breaking strength and lowered total cholesterol, VLDL cholesterol and triglycerides concentrations in the serum of broiler chickens.
\end{abstract}

Key words : Broiler Chickens, Cholesterol, Lactobacillus sporogenes, Performance, Serum Biochemical Profile J. Poult. Sci., 43 : 235-240, 2006

\section{Introduction}

To achieve high level of economic efficiency broiler chickens are raised under intensive production system in densely populated colonies or flocks. This inflicts considerable stress due to various factors such as transport, overcrowding, vaccination, etc. Probioitcs defined as live microbial feed supplement that beneficially affects the host animal by improving its intestinal microbial balance (Fuller, 1989) have been administered to counteract such stresses which subsequently improve body weight gain, feed conversion ratio and mortality in broiler chickens (Cavazzoni et al., 1998 ; Panda et al., 2000 ; Haung et al., 2004 ; Hooge et al., 2004). Moreover, it has been shown that probiotics could protect broilers against pathogens by colonization in the gastrointestinal tract (Pascual et al., 1999) and stimulation of

Received : February 16, 2006, Accepted : March 15, 2006

Correspondene to : Dr. A.K. Panda, Project Directorate on Poultry, Rajendranagar, Hyderabad 500 030, India

Tel : 91-40-24015651 Fax : 91-40-24017002 E-mail : akpanda59@rediffmail.com 
systemic immune responses (Quere and Girard, 1999 ; Panda et al., 2000).

The selection strategies for body weight gain in broiler chickens are resulting in lower quality poultry products due to higher body fat. The relatively larger amount of body fat in broiler carcass is not only a problem from consumer's preference point of view but also higher processing loss. Furthermore, the discarded abdominal and viscera fat increases waste management problems. Recently considerable attention has been paid to the potential of probiotics in altering lipid metabolism. This is due to the growing evidence that probiotics supplementation reduces cholesterol concentration in serum of chickens (Mohan et al., 1996). Supplementation of probiotics (Lactobacillus acidphilus, Bifidobacterium bifidum and Aspergillus oryzae) at $100 \mathrm{mg}$ per $\mathrm{kg}$ in the diet of broiler chickens significantly reduced the serum cholesterol concentration (Panda et al., 2001). Kalavathy et al. (2003) reported that dietary supplementation of a mix culture of 12 strains of Lactobacillus at $0.1 \%$ in the basal diet of broilers resulted in higher body weight gain and lowered serum cholesterol concentration.

The most used groups in the production of probiotics are Lactobacilli. It is the non-spore bearing lactic acid bacteria such as Lactobacillus acidphilus, Lactobacillus bulgaricus and Lactobacillus planatarum widely studied as probiotics (Abdulrahim et al., 1996). Lactobacillus sporogenes, (LS) a spore bearing lactic acid bacteria, which is stable, resistance to high temperature and tolerance to acid and bile salts (Cavazzoni et al., 1998) is currently gaining momentum for use as probiotic. Lactobacillus sporogenes grows well, inhabits in intestine and excellent in production of biologically active lactic acid and digestive enzymes. The affinity for acidic $\mathrm{pH}$ and high tolerance to bile salts, the spore germinates and proliferates in the digestive tract of poultry (Han et al., 1984). The information available on the use of L. sporogenes for enhancing performance of broiler chicken is scanty and to our knowledge the effect on altering serum lipid profile is not reported. Therefore, the present investigation is conducted to evaluate the effect of $L$. sporogenes on performance and serum biochemical and lipid profiles of commercial broiler chickens during 0 to 6 weeks of age.

\section{Materials and Methods}

\section{Stock, Husbandry and Diet}

One hundred and twenty, day-old commercial broiler chicks (Krishibro) were wing banded, vaccinated against Marek' disease and distributed in a completely randomized design into 3 groups of 40 chicks each, which was further replicated to 8 . The chicks of each replicate were housed at random in the pens of wire floored battery brooders having provision of feeders, waterers and faecal trays from 1 to 42 days of age. The chicks were placed on one of three dietary treatments : basal, basal with probiotic supplementation at a rate of 100 or $200 \mathrm{mg}$ per $\mathrm{kg}$ feed. The group not supplemented with probiotic served as control. The probiotic used in the study was a commercial preparation containing Lactobacillus sporogenes with 6, 000 million spores per $\mathrm{g}$ of the product. The experimental diets were formulated to meet the Bureau of Indian Standard nutrient recommendations (BIS, 1992) and the composition is presented in (Table 1). All birds were reared under uniform managemental conditions throughout the experimental period.

\section{Experimental Procedures}

\section{Body Weight and Feed Conversion Ratio}

Individual body weight of chicks and replicatewise feed intakes were recorded at weekly intervals through out the experimental period. Feed conversion ratio was calculated as the weight gain per feed intake. Mortality was monitored on daily basis.

\section{Serum Bio-chemical Parameters}

On $35^{\text {th }}$ day of experimental feeding $3 \mathrm{ml}$ of blood was collected from brachial vein from 12 birds in each treatment. Subsequently serum was separated and the levels of Ca (AOAC, 1990), P (Fiske and Subba Row, 1925), protein (Doumas et al., 1971), SGOT, SGPT (Reitman and Frankel, 1957) and alkaline phosphatase (ALP) activity (Bergmeyer, 1974) in the serum were estimated. On $42^{\text {nd }}$ day, another $3 \mathrm{ml}$ of blood from 12 birds in each dietary treatment was collected for estimation of serum cholesterol. The serum cholesterol (Zlaktis et al., 1953), HDL cholesterol (Demacker and Hifmans, 1980), serum triglycerides (Fossati and Lorenzo, 1982) were estimated by using respective diagnostic kits (Qualigens India. Pvt. Ltd., Catalogue no. 72201-04). VLDL cholesterol was calculated from triglycerides by dividing the factor 5 . The LDL 
Table 1. Composition of experimental diets (per $100 \mathrm{~kg}$ )

\begin{tabular}{lcc}
\hline \hline \multicolumn{1}{c}{ Ingredient } & Starter $(0-3 \mathrm{wk})$ & Finisher (4-6wk) \\
\hline Maize & 57.08 & 65.80 \\
Soybean meal & 37.00 & 29.50 \\
Deoiled rice bran & 2.30 & 1.51 \\
Oyster shell grit & 0.90 & 1.00 \\
Dicalcium phosphate & 1.90 & 1.38 \\
Common salt & 0.40 & 0.40 \\
DL-Methionine & 0.17 & 0.08 \\
Choline chloride & 0.10 & 0.10 \\
Vitamin premix ${ }^{1}$ & 0.05 & 0.05 \\
Mineral premix ${ }^{1}$ & 0.10 & 0.10 \\
$\quad$ Nutrient composition & & \\
Analyzed (\%) & & \\
Crude protein & 23.08 & 20.10 \\
Calcium & 1.05 & 0.90 \\
Available phosphorus & 0.45 & 0.35 \\
Calculated & & \\
Metablizable energy (kcal/kg) & 2802 & 2910 \\
Lysine (\%) & 1.20 & 1.01 \\
Methionine (\%) & 0.50 & 0.38 \\
\hline
\end{tabular}

${ }^{1}$ Supplies per kg diet : Vitamin A, 16,500 IU ; vitamin $\mathrm{D}_{3}, 3200$ ICU ; vitamin E, $12 \mathrm{mg}$; vitamin $\mathrm{K}, 2 \mathrm{mg}$; vitamin $\mathrm{B}_{1}, 1.2 \mathrm{mg}$; vitamin $B_{2} 10 \mathrm{mg}$; vitamin $B_{6}, 2.4 \mathrm{mg}$; vitamin $B_{12}, 12 \mu \mathrm{g}$; niacin, $18 \mathrm{mg}$; pantothenic acid, $12 \mathrm{mg}$; $\mathrm{Mn}, 90 \mathrm{mg} ; \mathrm{Zn}, 72$ $\mathrm{mg} ; \mathrm{Fe}, 60 \mathrm{mg} ; \mathrm{Cu}, 10 \mathrm{mg} ; \mathrm{I}, 1.2 \mathrm{mg}$.

cholesterol was calculated by using the formula : LDL cholesterol $=$ Total cholesterol - HDL cholesterol-VLDL cholesterol.

\section{Leg Abnormality Score}

On $43^{\text {rd }}$ day of the experimental feeding, leg scoring was done (Watson et al., 1970) to find out leg abnormalities, if any, by giving the numerical score as : 0 -Completely normal leg ; 1 -Slightly swelling of the tibio-metatarsal joint ; 2-Marked swelling of the tibio-metatarsal joint ; 3-Swelling and slight slipping of the achilles tendon ; 4-Swelling combined with marked degree of slipping of the achilles tendon.

\section{Bone Ash and Bone Breaking Strength}

On day $43^{\text {rd }}$, one bird from each replicate in each dietary treatment was selected at random and sacrificed by cervical dislocation. Both the tibiae were freed from soft tissue and diaphysis, defatted by soaking in petroleum ether for $48 \mathrm{~h}$ and dried at $100^{\circ} \mathrm{C}$ for $12 \mathrm{~h}$. The right and left tibiae were used for determination of bone ash and bone strength, respectively. Dried bone samples were ashed at 600 $\pm 30^{\circ} \mathrm{C}$ for $12 \mathrm{~h}$ for estimation of bone ash (AOAC, 1990). Breaking strength on the left tibia was determined by universal testing machine (EZ test,
120891-04, Shimadzu-Japan).

\section{Statistical Analysis}

Data were subjected to statistical analysis under completely randomized design employing one-way analysis of variance (Snedecor and Cochran, 1989). The means of different treatments were compared with Duncan multiple range tests (Duncan, 1955). Significance was considered at $\mathbf{P}<0.05$ level.

\section{Results}

The performance of broiler chickens fed diet supplemented with Lactobacillus sporogenes (probiotic) is depicted in Table 2. Body weight gain (BWG) increased significantly by dietary supplementation of $100 \mathrm{mg}$ probiotics per kg diet. However, no further benefits on BWG could be observed by increasing the level of supplementation from 100 to $200 \mathrm{mg}$ per $\mathrm{kg}$. The feed conversion ratio (FCR) improved significantly in the $100 \mathrm{mg}$ probiotic supplemented dietary group as compared to control. The FCR was intermediate in the dietary group supplemented with $200 \mathrm{mg}$ probiotic per $\mathrm{kg}$ diet. Mortality was not influenced due to supplementation of probiotic in the diet. Leg abnormality score (Table 2) was not influenced due to $L$. sporogenes supplementation in the diet. However, the bone breaking strength and bone ash content increased significantly due supplementation of $L$. sporogenes at $100 \mathrm{mg}$ per kg diet. No further benefits in these two parameters could be observed by increasing the supplementation from 100 to $200 \mathrm{mg}$ per $\mathrm{kg}$ diet.

The serum concentration of protein and calcium (Ca) (Table 3) increased significantly due to dietary supplementation of $L$. sporogenes. However, no difference could be noticed between the levels of supplementation. Neither concentration of inorganic phosphorus (iP) nor activities of enzymes such as SGOT, SGPT and ALP in serum were influenced due to $L$. sporogenes supplementation.

The effect of dietary supplementation of $L$. sporogenes on serum lipid in broiler chicken is shown in Table 4. Serum total cholesterol was significantly lowered in broilers supplemented with $L$. sporogenes at $100 \mathrm{mg}$ per $\mathrm{kg}$ diet. There was no significant difference in HDL cholesterol of birds fed with or without $L$. sporogenes. However, the serum LDL cholesterol was reduced significantly by dietary supplementation of $L$. sporogenes. Serum VLDL cholesterol and triglycerides followed the same trend as 
Table 2. Dietary supplementation of Lactobacillus sporogenes on performance of broiler chicken (0-6 wks)

\begin{tabular}{lcccc}
\hline \hline \multirow{2}{*}{ Attributes } & \multicolumn{3}{c}{ Probiotic $(\mathrm{mg} / \mathrm{kg}$ diet $)$} & \multirow{2}{*}{ SEM } \\
\cline { 2 - 4 } & 0 & 100 & 200 & 15.31 \\
\hline Body weight gain (g) & $1398^{\mathrm{b}}$ & $1508^{\mathrm{a}}$ & $1497^{\mathrm{a}}$ & 0.05 \\
Feed conversion ratio & $2.27^{\mathrm{a}}$ & $1.97^{\mathrm{b}}$ & $2.07^{\mathrm{ab}}$ & - \\
Mortality (\%) & 5.00 & 5.00 & 7.50 & 0.74 \\
Leg abnormality score & 1.00 & 1.00 & 0.58 & 0.29 \\
Tibia breaking strength (Newton) & $59.42^{\mathrm{b}}$ & $61.89^{\mathrm{a}}$ & $61.98^{\mathrm{a}}$ & 0.24 \\
Bone ash (\%) & $37.49^{\mathrm{b}}$ & $39.69^{\mathrm{a}}$ & $39.64^{\mathrm{a}}$ & 0.24 \\
\hline
\end{tabular}

${ }^{\mathrm{a}, \mathrm{b}}$ Means with different superscripts in a row differ significantly $(\mathrm{P}<0.05)$

Table 3. Dietary supplementation of Lactobacillus sporogenes on serum biochemical parameters of broiler chicken

\begin{tabular}{lcccc}
\hline \hline \multirow{2}{*}{ Attributes } & \multicolumn{3}{c}{ Probiotic $(\mathrm{mg} / \mathrm{kg}$ diet $)$} & \multirow{2}{*}{ SEM } \\
\cline { 2 - 4 } & 0 & 100 & 20 & 0.06 \\
\hline Protein $(\mathrm{mg} / \mathrm{d} l)$ & $4.25^{\mathrm{b}}$ & $4.84^{\mathrm{a}}$ & $4.90^{\mathrm{a}}$ & 0.04 \\
Calcium (mg/d $l)$ & $8.26^{\mathrm{b}}$ & $8.68^{\mathrm{a}}$ & $8.72^{\mathrm{a}}$ & 0.12 \\
Phosphorus (mg/d $l)$ & 4.68 & 4.62 & 4.59 & \\
Enzymes (IU/L) & & & & 0.61 \\
SGOT & 50.13 & 48.24 & 48.03 & 0.25 \\
SGPT & 25.65 & 25.28 & 24.91 & 0.22 \\
ALP & 38.97 & 38.51 & 38.61 & \\
\hline
\end{tabular}

${ }^{a, b}$ Means with different superscripts in a row differ significantly $(\mathbf{P}<0.05)$.

SGOT-Serum glutamic oxalo acetate transminase; SGPT-Serum glutamic pyruvate transaminase; ALPAlkaline phosphatase

Table 4. Dietary supplementation of Lactobacillus sporogenes on serum lipid concentrations $(\mathrm{mg} / \mathrm{dl})$ of broiler chicken

\begin{tabular}{lcccc}
\hline \multirow{2}{*}{ Attributes } & \multicolumn{3}{c}{ Probiotic $(\mathrm{mg} / \mathrm{kg}$ diet $)$} & \multirow{2}{*}{ SEM } \\
\cline { 2 - 4 } & 0 & 100 & 200 & \\
\hline Total cholesterol & $126.70^{\mathrm{a}}$ & $119.08^{\mathrm{b}}$ & $119.49^{\mathrm{b}}$ & 0.72 \\
HDL cholesterol & 74.27 & 72.24 & 72.20 & 0.94 \\
LDL cholesterol & $39.46^{\mathrm{a}}$ & $35.02^{\mathrm{b}}$ & $35.49^{\mathrm{b}}$ & 0.23 \\
VLDL cholesterol & $12.97^{\mathrm{a}}$ & $11.82^{\mathrm{b}}$ & $11.80^{\mathrm{b}}$ & 0.06 \\
Triglycerides & $64.89^{\mathrm{a}}$ & $59.14^{\mathrm{b}}$ & $59.10^{\mathrm{b}}$ & 0.30 \\
\hline
\end{tabular}

${ }^{\mathrm{a}, \mathrm{b}}$ Means with different superscripts in a row differ significantly $(\mathrm{P}<0.05)$.

HDL cholesterol-High density lipoprotein cholesterol ; LDL cholesterol-Low density lipoprotein cholesterol VLDL cholesterol-Very low density lipoprotein cholesterol.

that of LDL cholesterol. No further decrease in total cholesterol, LDL cholesterol or triglycerides concentration in serum was observed by increasing the supplementation from 100 to $200 \mathrm{mg}$.

\section{Discussion}

Dietary supplementation of Lactobacillus sporogenes at $100 \mathrm{mg}$ per $\mathrm{kg}$ diet significantly improved the body weight gain and feed conversion ratio in this experiment. Similarly, Han et al. (1984) found significant improvement in body weight gain and feed conversion ratio by supplementing chicken diets with $L$. sporogenes and Clostrodium butyricum. Consistent improvements in body weight gain of chickens by feeding a culture of $L$. sporogenes have also been reported by Kalbande et al. (1992). In two separate trials with day old broiler chicks on $L$. sporogenes supplementation, Cavazzoni et al. (1998) reported significant improvement in growth and feed conversion ratio during 1 to 49 days of age. $L$. 
sporogenes are functional in prophylactic and curative treatments without causing any pathological and pharmacological side effects and are good source of certain digestive enzymes such as amylase, protease and lipase for optimum digestion and absorption of nutrients. Thus, the significant improvement in body weight gain and feed conversion ratio in this experiment could be attributed to a better microbial environment in the gut, which in turn might have enhanced digestion, absorption and utilization of nutrients (Panda et al., 2000).

No information in literature is available with regard to the influence of $L$. sporogenes on bone breaking strength and bone ash content. However, our finding suggests that $L$. sporogenes had a positive influence in these two parameters. This could be attributed to higher assimilation of calcium (Mohan et al., 1995) in the bone, which might have created a greater resistance resulting in higher strength. This hypothesis is further supported by the increased concentration of $\mathrm{Ca}$ in serum (Table 3 ) in probioticsupplemented group.

Dietary supplementation of probiotic in the present study resulted in higher serum concentration of protein and $\mathrm{Ca}$. This could be attributed to the favourable environment in intestinal tract due to feeding of $L$. sporogenes, which might have helped to digest and absorb more nitrogen and calcium (Mohan et al., 1995) resulting in higher concentration in serum. Similar trend was observed in our earlier studies (Panda et al., 2003). The non difference in concentration of inorganic phosphorus (iP) and activities of enzymes (SGOT, SGPT and ALP) due to $L$. sporogenes supplementation was in agreement with the findings of Baidya et al. (1994).

Similar cholesterol depressing effect due to $L$. sporogenes supplementation in broiler chicken was observed by Joy and Samuel (1997). Probiotic supplementation significantly reduced the serum LDL cholesterol (Kalavathy et al., 2003) and triglycerides (Santoso et al., 1995) in broiler chicken. The findings of our study and also from previous studies indicated that probiotic feeding has a cholesterol depressing effect in broiler chickens. However the mechanism(s) of action for producing hypocholesterolemic effect is not yet fully understood. Nelson and Gilliand (1984) reported that some of the microorganisms present in the probiotic preparation could utilize the cholesterol present in the gas- trointestinal tract for their own metabolism, thus reducing the amount absorbed. Mohan et al. (1995) reported that the reduction in serum cholesterol could be attributable to reduced absorption and/or synthesis of cholesterol in the gastro-intestinal tract by probiotic supplementation (Mohan et al., 1995). Lactobacillus acidophillus reduces the cholesterol in the blood by deconjugating bile salts in the intestine, thereby preventing them from acting as precursors in cholesterol synthesis (Abdulrahim et al., 1996). Lactobacillus has a high bile salt hydrolytic activity, which is responsible for deconjugation of bile salts (Surono, 2003). Deconjugated bile acids are less soluble at low $\mathrm{pH}$ and less absorbed in the intestine and is more likely to excreted in faeces (Klaver and van der Meer, 1993). Probiotic microorganism inhibits hydroxymethyl-glutaryl-coenzyme A, an enzyme involved in the cholesterol synthesis pathway there by decrease cholesterol synthesis (Fukushima and Nakano, 1995).

In conclusion, it is concluded that dietary supplementation of Lactobacillus sporogenes $\left(6 \times 10^{8}\right.$ spore per g) at $100 \mathrm{mg}$ per $\mathrm{kg}$ diet significantly enhanced body weight gain, improved feed conversion ratio, bone ash and bone breaking strength and lowered total cholesterol, VLDL cholesterol and triglycerides concentrations in the serum of broiler chickens.

\section{References}

Abdulrahim SM, Haddadin MSY, Hashlamoun EAR and Robinson RK. The influence of Lactobacillus acidophilus and bacitracin on layer performance of chickens and cholesterol content of plasma and egg yolk. British Poultry Science, 37 : 341-346. 1996.

AOAC. Association of Official Analytical Chemists. Official Methods of Analysis of the Association of Official Analytical Chemists, Virginia, USA. 1990.

Baidya, N, Mandal L, Sarkar SK and Banerjee GC. Combined feeding of antibiotic and probiotic on the performance of broiler. Indian Journal of Poultry Science, 29 : 228-231. 1994.

BIS. Indian Standard : Poultry feed specifications, $4^{\text {th }}$ revision, Bureau of Indian Standards. New Delhi. 1992.

Bergmyer HU. In methods of Enzymatic Analysis. Vol. 11. Academic Press. Inc ; USA. 1974.

Cavazzoni V, Adami A and Castrovilli C. Performance of broiler chickens supplemented with Bacillus coagulans as probiotic. British Poultry Science, 39 : 526-529. 1998.

Demacker PNM and Hifmans AGM. A study on the use of polyethylene glycol in estimating cholesterol in highdensity lipoproteins. Clinical Chemistry, $26: 1775^{-}$ 1779. 1980. 
Doumas BT, Watson WA and Biggs HG. Albumin standard and the measurement of serum albumin with bromocresol green. Clinical Chemistry Acta, 31 : 87. 1971.

Duncan DB. Biometrics, 11 : 1-42. 1955.

Fiske $\mathrm{CH}$ and Subba Row Y. The colorimetric determination of phosphorus. Journal of Biological Chemistry, 66 : 375-400. 1925.

Fossati P and Lorenz P. Serum triglycerides determined colorimetrically with an enzyme that produces hydrogen peroxide. Clinical Chemistry, 28 : 2007. 1982.

Fukushima $\mathbf{M}$ and Nakano, M. The effect of probiotic on faecal and liver lipid classes in rats. British Journal of Nutrition, 73 : 701-710. 1995.

Fuller R. Probiotics in man and animals. Journal of Applied Bacteriology, 66 : 365-378. 1989.

Han IK, Lee SC, Lee JH, Lee KK and Lee JC. Studies on the growth promoting effects of probiotics. 1. The influence of Lactobacillus sporogenes on the growing performance and the changes in microbial flora of the feces and intestinal contents. Korean Journal of Animal Sciences, 26 : 150-157. 1984.

Haung MK, Choi YJ, Houde R, Lee JW and Zhao X. Effects of Lactobacilli and an acidophilus fungus on the production performance and immune responses in broiler chickens. Poultry Science, 83 : 788-795. 2004.

Hooge DM, Ishimaru H and Sims MD. Influence of dietary Bacillus subtilis C-3102 spores on live performance of broiler chickens in four controlled pen trials. Journal of Applied Poultry Research, 13 : 222-228. 2004.

Joy AD and Samuel JJ. Effect of probiotic supplementation on the performance of broilers. Journal Veterinary and Animal Sciences, 28 : 10-14. 1997.

Kalavathy R, Abdullah N, Jalaludin S and Ho YW. Effects of lactobacillus cultures on growth performance, abdominal fat deposition, serum lipids and weight of organs of broiler chickens. British Poultry Science, 44 : 139-144. 2003.

Kalbande VH, Gaffar MA and Deshmukh SV. Effect of probiotic and nitrofurin on performance of growing commercial pullets. Indian Journal of Poultry Science, 27 : 116-117. 1992.

Klaver FAM. and van der Meer R. The assumed assimilation of cholesterol by Lactobacilli and Bifidobacterium bifidum is due to their bile salt deconjugating activity. Applied Environmental Microbiology, 59 : 1120-1124. 1993.

Mohan B, Kadirvel R, Bhaskaran M and Natarajan A. Effect of probiotic supplementation on serum/yolk cholesterol and on egg shell thickness in layers. British Poultry
Science, 36 : 799-803. 1995.

Mohan B, Kadirvel R, Bhaskaran M and Natarajan A. Effect of probiotic supplementation on growth, nitrogen utilization and serum cholesterol in broilers. British Poultry Science, 37 : 395-401. 1996.

Nelson CR and Gilliland SE. Cholesterol uptake by Lactobacillus acidophillus. Journal of Dairy Science, 67 (supplement). 1984.

Panda AK, Reddy MR, Ramarao SV, Raju MVLN, and Praharaj NK. Growth, carcass characterist ics, immunecompetence and response to Escherchia coli of broilers fed diets with various levels of probiotic. Archives Geflugelkonde, 64 : 152-156. 2000.

Panda AK, Reddy MR and Praharaj N K. Dietary supplementation of probiotic on growth, serum cholesterol and gut microflora of broilers. Indian Journal of Animal Science, 71 : 488-490. 2001.

Panda AK, Reddy MR, Ramarao SV and Praharaj NK. Production performances, serum / yolk cholesterol and immune competence of White Leghorn layers as influenced by dietary supplementation of probiotic. Tropical Animal Production, 35 : 85-94. 2003.

Pascual M, Hugas M, Badiola JI, Monfort JM and Garriga M. Lactobacillus salivarus CTC2197 prevents Salmonella enteritidis colonization in chickens. Applied Environmental Microbiology, 65 : 4981-4986. 1999.

Quere P and Girard F. Systemic adjuvant effect of cholera toxin in the chicken. Veterinary Immunology and Immuno-pathology, 70 : 134-141. 1999.

Reitman S and Frankel S. A Colorimetric method for the determination of serum glutamic oxaloacetic transminase and serum glutamic pyruvic transaminase. American Journal of Clinical Pathology, 20 : 56-59. 1957.

Santoso U, Tanaka K and Ohtani S. Effect of dried Bacillus subtilis culture on growth, body composition and hepatic lipogenic enzyme activity in female broiler chicks. British Journal of Nutrition, 74 : 523-529. 1995.

Snedecor GW and Cochran WG. Statistical methods. Oxford and IBH Publishing Company, New Delhi. 1989.

Surono IS. In vitro probiotic properties of indigenous dadih lactic acid bacteria. Asian-Australian Journal of Animal Sciences, $16:$ 726-731. 2003.

Watson LT, Ammerman CB, Miller SM and Harm RH. Biological assay of inorganic manganese for chicks. Poultry Science, 49 : 1548-1554. 1970.

Zlatkis A, Zak B, and Boyle AJ. A new method for the direct determination of serum cholesterol. Journal of Laboratory Clinical Medicine, 41 : 486-492. 1953. 